\title{
Undifferentiated Carcinoma
}

National Cancer Institute

\section{Source}

National Cancer Institute. Undifferentiated Carcinoma. NCI Thesaurus. Code C3692.

A usually aggressive malignant epithelial neoplasm composed of atypical cells which do not display evidence of glandular, squamous, or transitional cell differentiation. 